\title{
PENGARUH EKSTRAK GULMA SIAM, SALIARA, DAN KEMUNING TERHADAP BUSUK LUNAK NANAS (Erwinia chrysanthemi) SECARA IN VITRO
}

\author{
Nur Aeni, Titik Nur Aeny, Efri \& Cipta Ginting \\ Jurusan Agroteknologi, Fakultas Pertanian Universitas Lampung \\ Jl. Prof. Soemantri Brodjonegoro, No. 1 Bandar Lampung 35145 \\ E-mail: aeni4982@gmail.com
}

\begin{abstract}
ABSTRAK
Salah satu penyakit penting tanaman nanas adalah penyakit busuk lunak nanas yang disebabkan oleh Erwinia chrysanthemi. Pemanfaatan pestisida nabati menjadi alternatif pengendalian penyakit busuk lunak nanas yang ramah lingkungan. Tujuan penelitian ini untuk mengetahui pengaruh ekstrak gulma siam, saliara dan kemuning terhadap pertumbuhan $E$. chrysanthemi secara in vitro dan mengetahui pengaruh taraf konsentrasi ekstrak gulma siam, saliara dan kemuning terhadap pertumbuhan E. chrysanthemi secara in vitro. Penelitian ini dilakukan di Laboratorium Bioteknologi Fakultas Pertanian Universitas Lampung pada bulan Maret sampai bulan Juli 2016. Pelaksanaan penelitian meliputi penyiapan isolat E.chrysanthemi, penyiapan ekstrak gulma siam, saliara dan kemuning, penyiapan media nutrient agar (NA), penyiapan medium berisi E.chrysanthemi, pengujian penghambatan ekstrak gulma siam, saliara dan kemuning terhadap pertumbuhan E.chrysanthemi secara in vitro, pengamatan dan pengumpulan data. Penelitian ini menggunakan Rancangan Acak Lengkap dengan 5 taraf konsentrasi. Taraf konsentrasi yang digunakan adalah $0 \%, 20 \%, 40 \%, 60 \%$ dan $80 \%$ dan diulang sebanyak 3 kali. Hasil penelitian menunjukkan bahwa ekstrak gulma siam dan saliara dengan taraf yang diuji terlihat adanya zona penghambatan. Pada perlakuan ekstrak kemuning dengan taraf konsentrasi 0\%-80\% tidak tampak adanya zona penghambatan di sekitar cakram. Semakin tinggi taraf konsentrasi ekstrak gulma siam dan saliara semakin menghambat pertumbuhan E.chrysanthemi secara in vitro.
\end{abstract}

Kata kunci: Ekstrak, Erwinia chrysanthemi, gulma siam, kemuning, penghambatan, saliara

\section{PENDAHULUAN}

Nanas (Ananas comosus L. Merr.) merupakan buah olahan ekspor Indonesia. Bahkan indonesia merupakan eksportir nanas kaleng ketiga di dunia setelah Thailand dan Filipina. Jumlah ekspor nanas Indonesia mencapai 450.000 ton/tahun yang disuplai dari PT Great Giant Peneaplle, Lampung Tengah (Nixon, 2009).

Berdasarkan data Badan Pusat Statistik (2016), produksi buah nanas di Indonesia pada tahun 2013 sebesar 1.837.159 ton atau naik dari tahun sebelumnya (2012) 1.781.899 ton. Produksi tersebut berasal dari beberapa daerah di Indonesia, salah satunya Provinsi Lampung yang memiliki produksi buah nanas terbesar di Indonesia pada tahun 2013, yaitu sebesar 722.620 ton.

Dalam upaya meningkatkan produksi nanas untuk proses memenuhi kebutuhan ekspor, Indonesia telah melakukan budidaya yang baik yang selanjutnya diharapkan akan menghasilkan produksi yang tinggi. Namun demikian, di dalam usaha peningkatan produksi nanas, masih ditemukan berbagai kendala, salah satunya adalah serangan organisme pengganggu tanaman (OPT) khususnya patogen atau organisme penyebab penyakit. Salah satu penyakit tanaman nanas yang dilaporkan oleh Prasetyo dan Aeny (2014) adalah penyakit busuk buah (fruit collapse) yang disebabkan oleh Erwinia chrysanthemi. Penyakit ini sudah banyak dilaporkan di berbagai negara penghasil nanas sebagai penyakit yang berbahaya dan menimbulkan kerugian yang besar (Kaneshiro, dkk., 2008 dan Sahilah, dkk., 2008).

Pada umumnya pengendalian penyakit tanaman yang disebabkan oleh bakteri dilakukan secara kimiawi dengan menggunakan bakterisida, yaitu bahan kimia yang dapat membunuh bakteri. Namun, penggunaan bahan kimia banyak dikhawatirkan dapat menimbulkan dampak negatif bagi pengguna maupun lingkungan. Selain itu, harga pestisida yang semakin mahal juga menjadi permasalahan bagi petani. Saat ini, pengendalian yang murah, aman dan ramah lingkungan menjadi prioritas utama. Salah satunya adalah dengan cara pemanfaatan tumbuhan yang berperan sebagai pestisida nabati yang bersifat ramah lingkungan. Selain ramah lingkungan karena mudah terurai dan tidak meninggalkan residu, 
bahan-bahan pestisida nabati pada umumnya mudah ditemukan, mudah dibuat, dan mudah diaplikasikan (Suharjo dan Aeny, 2011).

Banyak jenis tumbuhan yang dilaporkan dapat dijadikan sebagai bahan pestisida nabati, atau khususnya bakterisida nabati. Beberapa diantaranya adalah Chromolaena odorata atau guilma siam (Suharjo dan Aeny, 2011), Lantana camara atau saliara (Dini, dkk., 2011) dan Murraya paniculata atau kemuning (Kartika, 2007). Ketiga jenis tumbuhan tersebut dilaporkan mengandung senyawa antibakteri. Gulma siam mengandung senyawa alkaloid dan flavonoid (Adegbite dan Adesiyan, 2011). Novianti (2013) melaporkan senyawa yang terkandung dalam daun saliara adalah flavonoid, tanin dan terpenoid. Dosoky, dkk. (2016) melaporkan bahwa daun kemuning mengandung senyawa kimia yang merupakan metabolit sekunder seperti minyak atsiri dan flavonoid. Senyawa antibakteri tersebut diduga dapat mengendalikan patogen tanaman. Namun, saat ini belum ada laporan penggunaan gulma siam, saliara dan kemuning sebagai pestisida nabati dalam mengendalikan penyakit busuk lunak tanaman nanas. Oleh karena itu, perlu dilakukan pengujian ekstrak gulma siam, saliara dan kemuning dalam menghambat pertumbuhan E. chrysanthemi.

\section{BAHAN DAN METODE}

Penelitian ini dilakukan di Laboratorium Bioteknologi Fakultas Pertanian Universitas Lampung. Pelaksanaan penelitian dimulai dari bulan Maret 2016 hingga bulan Juli 2016.

Pada penelitian ini dilakukan penyiapan isolat E.chrysanthemi, penyiapan ekstrak gulma siam, saliara dan kemuning, penyiapan media nutrient agar (NA), penyiapan medium berisi E.chrysanthemi, pengujian penghambatan ekstrak gulma siam, saliara dan kemuning terhadap pertumbuhan E.chrysanthemi secara in vitro, pengamatan dan pengumpulan data.

Isolat bakteri $E$. chrysanthemi didapatkan dari koleksi Laboratorium Bioteknologi Fakultas Pertanian Universitas Lampung. Sebelum digunakan dalam penelitian ini, isolat bakteri terlebih dahulu diremajakan.

Ekstrak gulma siam diambil dari bagian bunga, saliara dan kemuning diambil dari bagian daun masingmasing sebanyak 100 gram. Masing-masing bagian tanaman dirajang lalu ditambahkan air steril sebanyak $100 \mathrm{ml}$. Selanjutnya, bagian tanaman yang telah direndam, dihaluskan dengan mortar dan disaring dengan kain sifon dan hasil air saringan tersebut dijadikan sebagai ekstrak murni $100 \%$. Tingkat konsentrasi yang digunakan yaitu $0 \%, 20 \%, 40 \%, 60 \%$ dan $80 \%$.
Media NA disiapkan dengan cara mencampurkan bubuk NA sebanyak $28 \mathrm{~g}$ ke dalam $1.000 \mathrm{ml}$ aquades lalu diaduk rata dan kemudian direbus sampai mendidih untuk melarutkan bubuk NA. Setelah itu, tabung erlenmeyer yang berisi media dimasukkan ke dalam plastik tahan panas dan disterilkan pada suhu $121^{\circ} \mathrm{C}$ dan tekanan 1 atm selama 15 menit.

Penyiapan media berisi E. chrysanthemi dilakukan dengan cara menambahkan dua ose bakteri ke dalam $5 \mathrm{ml}$ air steril. Selanjutnya campuran tersebut dihomogenkan dengan menggunakan rotamixer. Suspensi tersebut dimasukkan ke dalam $100 \mathrm{ml}$ media NA steril yang masih cair dan digoyang-goyang supaya tercampur rata dengan media. Selanjutnya campuran media dan suspensi bakteri tersebut dituang ke cawan dan digunakan sebagai media pengujian secara in vitro

Pengujian penghambatan ekstrak gulma siam, saliara dan kemuning terhadap pertumbuhan E.chrysanthemi secara in vitro dilakukan dengan menggunakan metode difusi agar. Potongan cakram kertas saring berdiameter $0,5 \mathrm{~cm}$ direndam dalam ekstrak gulma siam, saliara dan kemuning sesuai dengan konsentrasi perlakuan selama 2 menit agar meresap sampai jenuh. Kemudian, cakram kertas yang telah direndam tersebut ditiriskan lalu diletakkan pada permukaan media NA yang sebelumnya telah dicampur dengan biakan E. chrysanthemi. Selanjutnya, cawan petri diinkubasi selama 24 jam dalam suhu kamar

Pengamatan pada ketiga subpercobaan dilakukan terhadap diameter zona penghambatan yang terbentuk di sekeliling cakram kertas saring yang telah direndam pada masing-masing ekstrak sesuai perlakuan. Zona penghambatan ditandai dengan adanya daerah bening di sekitar potongan kertas saring. Diameter zona penghambatan diukur berdasarkan nilai rata dari ukuran diameter yang terpendek dan terpanjang. Data yang didapatkan kemudian diuji secara statistik

Penelitian terdiri dari tiga subpercobaan. Masingmasing percobaan menggunakan Rancangan Acak Lengkap (RAL), dengan 5 perlakuan yang diulang sebanyak 3 kali. Kelima perlakuan tersebut adalah taraf konsentrasi 0\% (air steril), 20\%, 40\%, 60\%, dan 80\%. Data hasil pengamatan dianalisis dengan sidik ragam (Anova) dan dilanjutkan dengan perbandingan polinomial ortogonal

\section{HASIL DAN PEMBAHASAN}

\section{Hasil Penelitian}

Dari hasil pengamatan terhadap pertumbuhan bakteri E.chrysanthemi pada perlakuann ekstrak gulma 
siam dan saliara dengan taraf konsentrasi yang diuji $40 \%$, $60 \%$ dan $80 \%$ terlihat adanya zona bening di sekitar cakram kertas yang berisi ekstrak. Zona bening tersebut menunjukkan bahwa tidak ada pertumbuhan bakteri E.chrysanthemi. Pada perlakuan ekstrak kemuning tidak terbentuk zona bening atau tidak terjadi penghambatan pertumbuhan bakteri E.chrysanthemi.

Pengaruh ekstrak gulma siam terhadap diameter zona penghambatan bakteri E.chrysanthemi secara in vitro ditunjukkan pada Gambar 1. Gambar 1 menunjukkan bahwa semakin tinggi taraf konsentrasi yang digunakan pada ekstrak gulma siam semakin menghambat pertumbuhan E.chrysanthemi secara linier dengan persamaan $Y=0,0622 \mathrm{x}-0,02$. Setiap penambahan konsentrasi akan menambah efek penghambatan yang besar.

Pengaruh ekstrak saliara terhadap diameter zona penghamabatan $E$. chrysanthemi secara in vitro ditunjukkan pada Gambar 2. Gambar 2 menunjukkan bahwa semakin tinggi taraf konsentrasi yang digunakan pada ekstrak gulma saliara semakin menghambat pertumbuhan E.chrysanthemi secara linier dengan persamaan $\mathrm{Y}=0,04 \mathrm{x}+0,06$. Setiap penambahan konsentrasi akan menambah efek penghambatan yang besar. Pada perlakuan ekstrak kemuning dengan taraf konsentrasi $0 \%-80 \%$ tidak tampak adanya zona penghambatan E. chrysanthemi secara in vitro di sekitar cakram kertas.

Pembahasan

Hasil penelitian menunjukkan bahwa ekstrak gulma siam mampu menghambat pertumbuhan bakteri

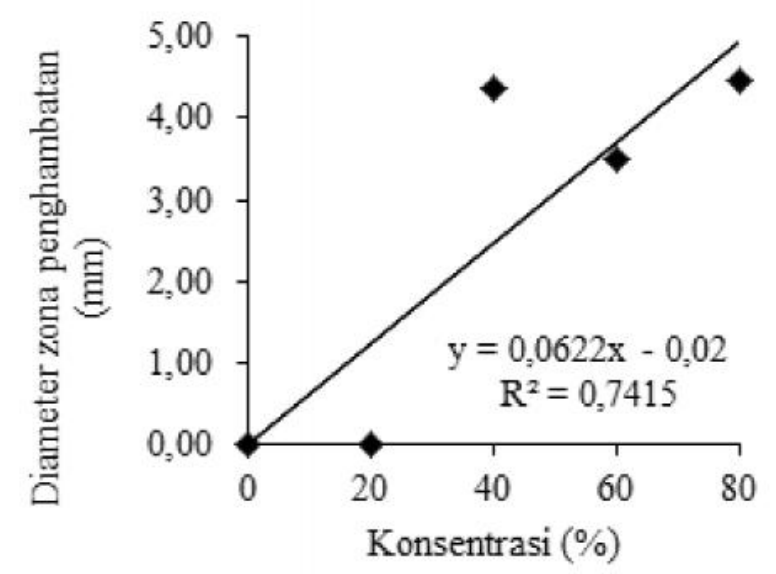

Gambar 1. Grafik pengaruh taraf konsentrasi ekstrak gulma siam terhadap diameter zona penghambatan $E$. chrysanthemi secara in vitro
E. chrysanthemi secara in vitro. Perlakuan ekstrak gulma siam dalam menghambat pertumbuhan E.chrysanthemi diduga karena adanya senyawa antibakteri yang terkandung dalam bunga gulma siam. Lamb (2005) melaporkan bahwa bunga gulma siam mengandung senyawa flavonoid. Senyawa flavonoid dilaporkan dapat menghambat sintesis asam nukleat, sehingga menyebabkan pertumbuhan sel bakteri terhambat. Flavonoid juga bekerja langsung pada membran sel bakteri yang menyebabkan kebocoran sel.

Hasil uji lanjut polinomial ortogonal pada taraf konsentrasi ekstrak gulma siam terhadap diameter zona penghambatan bakteri E. chrysanthemi membentuk pola linier. Pola linier menunjukkan bahwa semakin tinggi tingkat konsentrasi ekstrak gulma siam maka diameter zona penghambatan semakin besar. Penambahan zona penghambatan pertumbuhan $E$. chrysanthemi diduga karena konsentrasi yang tinggi mengandung senyawa antibakteri yang lebih banyak sehingga diameter zona penghambatannya menjadi lebih luas. Hal ini selaras dengan hasil penelitian Ulpa (2008) yang menunjukkan tingkat konsentrasi ekstrak gulma siam yang tinggi zona penghambatannya semakin luas.

Selain gulma siam dalam penelitian ini ekstrak saliara juga menunjukkan penghambatan pertumbuhan E. chrysanthemi secara in vitro. Hal ini juga sejalan dengan penelitian Novianti (2013) yang menyatakan bahwa eksrak L.camara dapat menghambat E.coli secara in vitro. Daun saliara dilaporkan mengandung senyawa aktif seperti tanin, flavenoid dan terpenoid. Senyawa kimia yang dapat larut dalam air dari ketiga senyawa tersebut adalah tanin (Irianty dan Yenti, 2014)

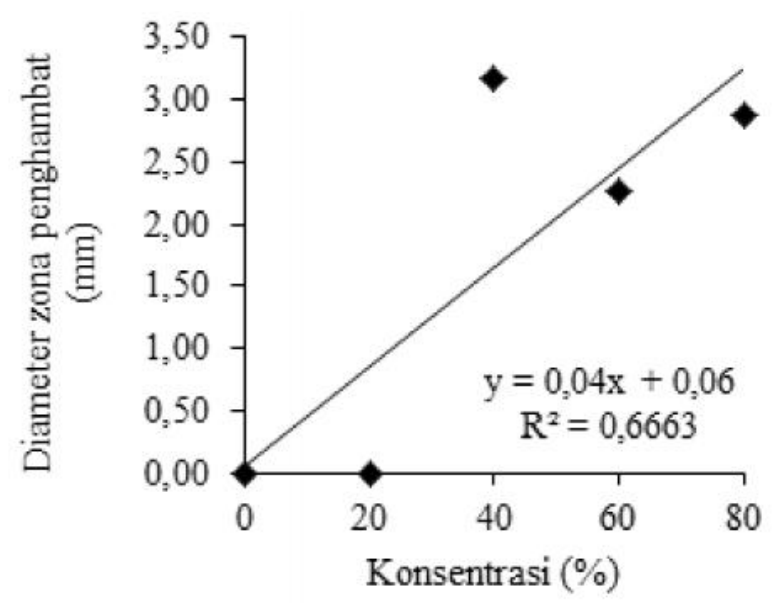

Gambar 2. Grafik pengaruh taraf konsentrasi ekstrak saliara terhadap diameter zona penghambatan $E$. chrysanthemi secara in vitro 
dan flavonoid (Arteel dan Sies,1999). Tanin dapat berperan sebagai antibakteri karena sifatnya yang dapat mengganggu kerja enzim, bereaksi dengan membran sel, dan dapat mengganggu fungsi materi genetik yang berada pada sel bakteri (Sulastrianah, dkk., 2014). Flavonoid dapat menyebabkan terjadinya kerusakan permeabilitas dinding sel bakteri (Bulan, dkk., 2004).

Hasil uji lanjut polinomial ortogonal pada taraf konsentrasi ekstrak saliara terhadap diameter zona penghambatan bakteri E. chrysanthemi membentuk pola linier. Pola linier menunjukkan bahwa semakin tinggi tingkat konsentrasi ekstrak saliara maka diameter zona penghambatan semakin besar. Penambahan zona penghambatan pertumbuhan $E$. chrysanthemi diduga karena konsentrasi yang tinggi mengandung senyawa antibakteri yang lebih banyak sehingga diameter zona penghambatannya menjadi lebih luas. Hal ini selaras dengan hasil penelitian Lestari, dkk. (2013) yang menunjukkan bahwa semakin tinggi tingkat konsentrasi ekstrak gulma saliara, semakin besar penghambatnnya terhadap pertumbuhan bakteri E. coli. Semakin tinggi konsentrasi fraksi ekstrak saliara, semakin besar penghambatan terhadap pertumbuhan Colletotrichum capsici (Sugiyem, 2015).

Senyawa aktif yang terdapat pada daun kemuning yaitu flavonoid dan terpenoid (Dosoky, dkk., 2016). Senyawa flavonoid dilaporkan dapat larut dalam air (Arteel dan Sies, 1999) sedangkan terpenoid umumnya larut dalam pelarut organik dan tidak larut dalam air (Ketaren 1987 dalam Ikawaty, 2015). Dengan demikian, diantara kedua senyawa aktif tersebut hanya salah satu senyawa yang bekerja dalam menghambat bakteri $E$. chrysanthemi secara in vitro yaitu flavonoid.

Perbedaan kondisi lingkungan tempat tumbuh dapat menyebabkan perbedaan jenis dan jumlah dari metabolit sekunder yang terkandung dalam tanaman. Dilaporkan bahwa tanaman Beladona stratomium dan Chinchona ledgeriana yang tumbuh pada intensitas cahaya yang penuh menghasilkan senyawa alkaloid yang lebih tinggi dibandingkan dengan yang tumbuh dibawah naungan (Sulandjari). Pada penelitian ini daun kemuning di ambil dari tempat yang tumbuh di bawah naungan. Dengan demikian diduga jumlah senyawa flavonoid yang tedapat pada tanaman kemuning lebih sedikit dibandingkan dengan gulma siam dan saliara, sehingga tanaman kemuning tidak dapat menekan pertumbuhan bakteri E. chrysanthemi secara in vitro

\section{KESIMPULAN}

Berdasarkan penelitian yang telah dilakukan dapat disimpulkan bahwa ekstrak gulma siam dan saliara dapat menghambat pertumbuhan E.chrysanthemi secara in vitro, sedangkan ekstrak kemuning tidak dapat menghambat. Semakin tinggi tingkat konsentrasi ekstrak gulma siam dan saliara semakin menghambat pertumbuhan E.chrysanthemi secara in vitro.

\section{DAFTAR PUSTAKA}

Adegbite, A.A dan S.O. Adesiyan. 2011. Root extracts of plants to control root-knot nematode on edible soybean. Obafemi Awolowo University. Nigeria. World Journal of Agricultural Sciences 1(1): 18-21.

Arteel, G.E. dan H. Sies. 1999. Protection against peroxynitrite by cocoa polyphenol oligomers. FEBS Letters. 462: 167-170.

BPS (Badan Pusat Statistika). 2016. Produksi tanaman buah-buahan. Available online at http:// www.bps.go.id/site/pilihdata, [12 April 2016].

Bulan, R., S. Soedigdo., S. Achmad, dan Buchari. 2004. Lantaden $X_{R}$ glikosida dari daun Lantana camara L. Jurnal Matematika dan Sains 9(1): 209-213.

Dini, I., Muharram dan S. Faika. 2011. Potensi ekstrak tumbuhan tembelekan (Lantana camara Linn.) dalam menghambat pertumbuhan bakteri Staphylococcus aureus dan Escherichia coli. Bionature. 12(1): 21-25.

Dosoky, N.S., P. Satyal., T.P. Gautam., dan W.N. Setzer. 2016. Composition and biological activities of Murraya paniculata (L.) jack essential oil from Nepal. Articles Medicines. 3(7): 1-10.

Ikawaty, A.L. 2015. Ekstraksi minyak atsiri bunga krisan (Chrysanthemum cinerariaefolium) dengan pelarut etanol dan n-heksana. Tugas Akhir. Universitas Negeri Semarang. Semarang. $1-23$.

Irianty, S.I, dan S.R. Yenti. 2014. Pengaruh perbandingan pelarut etanol-air terhadap kadar tanin pada sokletasi daun gambir (Uncaria gambir Roxb). SAGU. 13(1): 1-7.

Kaneshiro, W.S., M. Burger., B.G. Vine., A.S. De Silva., dan A.M. Alvarez. 2008. Characterization of Erwinia chrysanthemi from a bacterial heart rot of pineapple outbreak in Hawaii. Plant Disease 92(10): 1444-1450. 
Kartika, D. 2007. Profil kromatogram dan aktivitas antibakteri ekstrak etanol daun kemuning (Murraya paniculata (L.) Jack.) terhadap bakteri Escherichia coli in vitro. Artikel Karya Tulis Ilmiah. Fakultas Kedokteran. Universitas Diponegoro.

Lamb, A.J. 2005. Antimicrobial activity of flavonoids. International Journal of Antimicrobial Agents 26: 343-356.

Lestari, A., M. Jamhari., dan I.N. Kundera. 2013. Daya hambat ekstrak daun tembelek (Lantana camara 1.) terhadap pertumbuhan bakteri Escherichia coli. e-Jipbiol. 1: 42-49.

Nixon, M.T. 2009. Buku Pintar Budidaya Tanaman Buah Unggul Indonesia. PT Agromedia Pustaka. Jakarta.

Novianti. 2013. Aktivitas antibakteri ekstrak etanol daun tembelekan (Lantana camara L.) terhadap Saphylococcus aureus dan Escherichia coli dengan metode mikrodilusi clsim07-A9. Jurnal Ilmiah Farmako Bahari 4(2): 1-11.

Prasetyo, J., dan T.N. Aeny. 2014. Pineapple fruit collapse newly emerging disease of pineapple in Lampung, Indonesia. Jurnal Hama dan Penyakit Tumbuhan Tropika. 14(1): 96-99.

Sahilah, A.M., L. Rozeita., M.S.U. Kalsum., dan R. Son. 2008. Typing of Erwinia chrysanthemi isolated from josapine pineapple in malaysia using antimicrobial susceptibility, plasmid profiles, ERIC-PCR and RFLP analysis. International Food Research Journal 15(3): 273-280.

Sugiyem,W. 2015. Pengaruh tingkat konsentrasi ekstrak Tagetes erecta L. dan Lantana camara L. terhadap pertumbuhan dan sporulasi Colletotrichum capsici secara in vitro. Skripsi.Universitas Lampung.

Suharjo, R., dan T.N. Aeny. 2011. Eksplorasi potensi gulma siam (Chromolaena odorata) sebagai biofungisida pengendali Phytophthora palmivora yang diisolasi dari buah kakao. Jurnal Hama dan Penyakit Tumbuhan Tropika 11(2): 201-209.

Sulandjari. Tanaman obat rauvolfia serpentina. Available online at http://lpp.uns.ac.id/bukuteks/images/ flippingbook/Tanaman \% 2520Obat $\% 2520$ Rauvolfia\%2520Serpentina, [7 September 2016].

Sulastrianah, Imran dan E.S. Fitria. 2014. Uji daya hambat ekstrak daun sirsak (Annona muricata L.) dan daun sirih (Piper betle L.) terhadap pertumbuhan bakteri Escherichia coli. Bagian Farmakologi FK UHO.

Ulpa, M. 2008. Studi habitat dan pengujian ekstrak gulma siam (Chromolaena odorata) dalam menghambat pertumbuhan bakteri penyebab penyakit layu pisang (Ralstonia sp.) secara in vitro. Skripsi. Fakultas Pertanian. Universitas Lampung. 